\title{
Metals Accumulation in Grey Mangrove (Avicennia marina (Forsk.) Vierh.) Inhabiting Tarut Bay, Eastern Saudi Arabia
}

\author{
H. B. Almahasheer ${ }^{1}$, W. A. Al-Taisan ${ }^{1} \&$ M. K. Mohamed ${ }^{1}$ \\ ${ }^{1}$ Department of Biology, Girls College of Science, University of Dammam, Kingdom of Saudi Arabia \\ Corresponding author: H. B. Almahasheer, Department of Biology, Girls College of Science, University of \\ Dammam, Kingdom of Saudi Arabia. E-mail: halmahasheer@ud.edu.sa
}

Received: April 6, 2013 Accepted: November 8, 2013 Online Published: December 15, 2013

doi:10.5539/jas.v6n1p137 URL: http://dx.doi.org/10.5539/jas.v6n1p137

\begin{abstract}
Mangrove forests are of special interest because of their metal accumulation potenials as they occur in environments characterized by an excess of toxic ions. In this current study, we investigated the accumulation capacity of (Avicennia marina), a dominant mangrove plant inhabiting Tarut Bay in Eastern Saudi Arabia. Samples comprising mangroves, water and soil from 10 locations of Tarut Bay were analyzed for 8 heavy metals including Boron, Iron, Manganese, Zink, Lead, Nickel, Cadimum and Cupper. In water samples, B (5.5 PPM) was the highest while $\mathrm{Cd}$ was absent, also soil samples contained higher B (27.2 PPM), while Cd was lacking in these samples too. Overall, the concentrations of heavy metals were higher in plant shoot as compared to water and soil samples. In plant shoot $\mathrm{Cu}$ level was highest (107.22 PPM), while $\mathrm{Cd}$ was the lowest in. Our results demonstrate that grey mangrove absorb and accumulate higher quantities of heavy metals and thus play a vital role via cleansing the coastal environment from such harmful heavy metals. Our findings asserted that grey mangrove is a promising candidate for the purpose of Phytostabilization of industrially polluted coastal shores.
\end{abstract}

Keywords: heavy metals, grey mangrove, accumulation, tarut bay, vegetation filters

\section{Introduction}

The Eastern Province is the largest geographical area in the Kingdom of Saudi Arabia, covering about $86 \%$ of the country's industrial zone. Since the discovery of oil, this area has undergone immense progress (Alayaf, 1993). The pollution of this area increased dramatically due to the industrial revolution. The main sources of this pollution are the burning of fossil fuel, petroleum industries, mining and smelting of metalliferous ores, municipal wastes, landfill leachates, fertilizers, pesticides and sewage (Al-Khateeb \& Leilah, 2005). The pollution of the environment by industrial, economic and social activities is one of the most important global problems, now adays (Kamal et al., 2004).

Due to their toxic effects, the contamination of heavy metals (HM) in the environment is a major global concern, which has provoked the emergence of phytoremediation technologies for cleaning soils (Baker et al., 1994; Salt et al., 1998; Terry \& Banuelos, 2000), streams (Dushenkov et al., 1995), mine wastes and sewage (Ait et al., 2004; Von \& Max, 1984; Xingmao \& Havelka, 2009) by the use of approximately 400 plant species, capable of accumulating toxic heavy metals. Phytoremediation means to remove contaminants from polluted soils and water bodies using plants, capable of absorbing, degrading or eliminating them (Salt et al., 1998). It is a clean, efficient, inexpensive and environmental friendly mechanism.

In the Gulf region, oil and chemicals enter the marine environment from different sources such as continued discharge of industrial waste and oil spills from ships (Literathy et al., 2002). The Gulf War of 1991 brought serious environmental damage to the region. The world's largest oil spill was estimated at about as much as 8 million barrels (Metz, 1993). Most of the shores of the Eastern Province of Saudi Arabia and, the coasts bordering Kuwait got saturated with crude oil during the Gulf War, and many researches had described the impact of oil spills during the Gulf War (Gundlach et al., 1993; Tawfiq \& Olsen, 1993; Jacob \& Al-Muzaini, 1995; Hashim et al., 1995; GESAMP, 2007; Hashem, 2007; Bejarano \& Michel, 2010; Danish, 2010).

Grey mangrove (Avicennia marina (Forssk.) Vierh) inhabit the Arabian Gulf and it is tolerant to relatively high salinity, together with low rainfall and high temperatures (Loughland \& Al-abdulkader, 2011). The phytoremediating role of grey mangroves, especially in cleaning the environment has been described by earlier 
reserchers (Mac Farlane \& Burchett, 2002; Mac Farine et al., 2003; Suresh \& Ravishankar, 2004; Mac Farlane et al., 2007; Isaiah et al., 2011). Many scientists have suggested the use of some other plants in phytoremediation including Phragmites, Tamarix, tobacco, sunflower, cordgrass, Salix, Typha, Arabis gemmifera and Thlaspi caerulescens (Kubota \& Takenaka, 2003; Zhao et al., 2003; Adler, 2007; Manousaki et al., 2007; Al-Taisan, 2009).

Tarut Bay is considered as one of the most important coastal zones in the Gulf region and water birds flock here during winter in huge numbers i.e. Approximately 58,000 water birds (Czudek, 2006). The ecosystem of Tarut Bay is exposed to many environmental constraints and several factors threatens the mangroves vegetation. Some of these threats includ anthropogenic activities such as building fishing ports and dams, invasion of sand dunes, and camel grazing on mangrove leaves (Parvaresh, 2011), heavy metals (Agoramoorthy et al., 2008) and sewage from industrial and residential areas (Tam \& Wong, 1997).

This current study aims at investigating the extent of heavy metals accumulation in mangrove plants, soils and water in the Tarut Bay. To the best of our knowledge this is the first about metal accumulation in mangrove plants, soils and water in the selected study. (Farraj et al., 2011) published a paper that analysed the accumulation of heavy metals in Cuttlefish in the Arabian Gulf. Al-Sulami et al. (2002) also analysed the distribution of toxic heavy metals in fishes, sediments and water along the eastern coast of Saudi Arabia. While it can be agreed that some of the objectives of the latter study tally with those of this present study, the difference is that this current study sampled different sites and goes further to verify the accumulation of these toxic substances in mangrove plants. Also, Sadiq \& Zaidi (1994) analysed the accumulation of metals in sediments and mangrove leaves from samples collected from Tarut Bay and Gurmah Island. This current study is similar to the above because it measures accumulation of heavy metals in soils (sediments) and mangrove plants in the Tarut Bay. However, this current study does not focus on Gurmah Island and it was conducted in 1994 which is relatively a long time ago, this reason necessitates this current analysis of metal accumulation in mangroves and sediments in Tarut Bay. Also, (Zyadah \& Taweel, 2013) verified the accumulation of heavy metals in fish and prawns at the Dammam Coast of the Arabian Gulf. Their analysis is different from this current study because it is based on fish and prawns while this current study looks at bioaccumulation mostly in mangroves, sediments and water.

\section{Material and Methods}

This study was carried out on grey mangroves communities inhabiting Tarut Bay located in the eastern Province of Saudi Arabia. Tarut Bay extends from the northern coast of the city of Dammam and ends at Ras Tanura, covering an area of 41 thousand hectares $\left(410 \mathrm{k}^{2}\right)$ as shown in Figure 1 (Scott, 1995). Ten sites were selected and samples been between December 2010 and January 2011. It was worth mentioning help was taken from maps of the General Directorate of Military Survey (2001), and by using the latest mobile GPS (Garmin nuvi 205W) as shown in (Figure $2 \&$ Table 1).

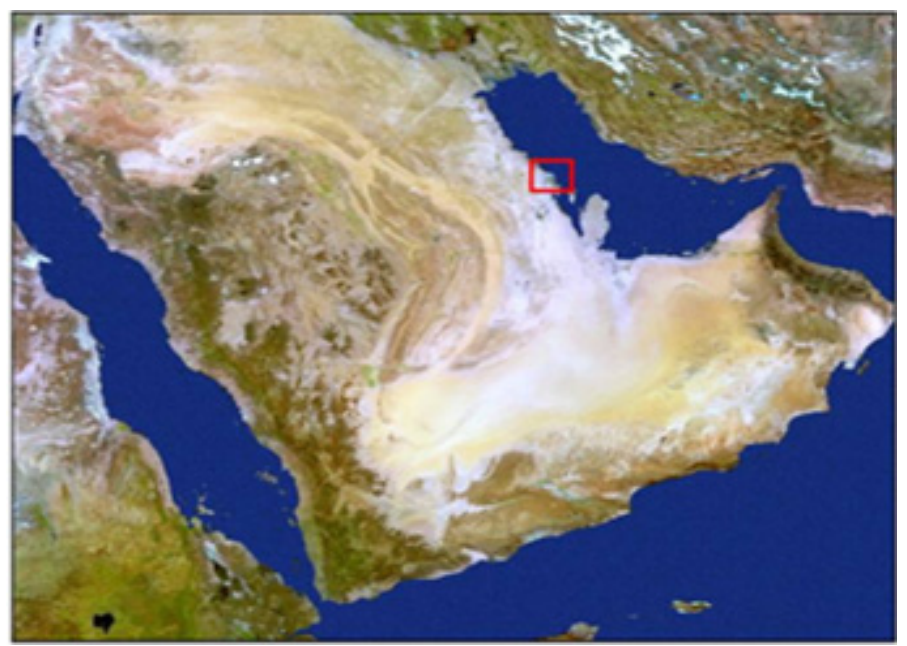

Figure 1. Satellite image showing the Tarut Bay under the study (picture from King Abdul-Aziz City for Science and Technology) 


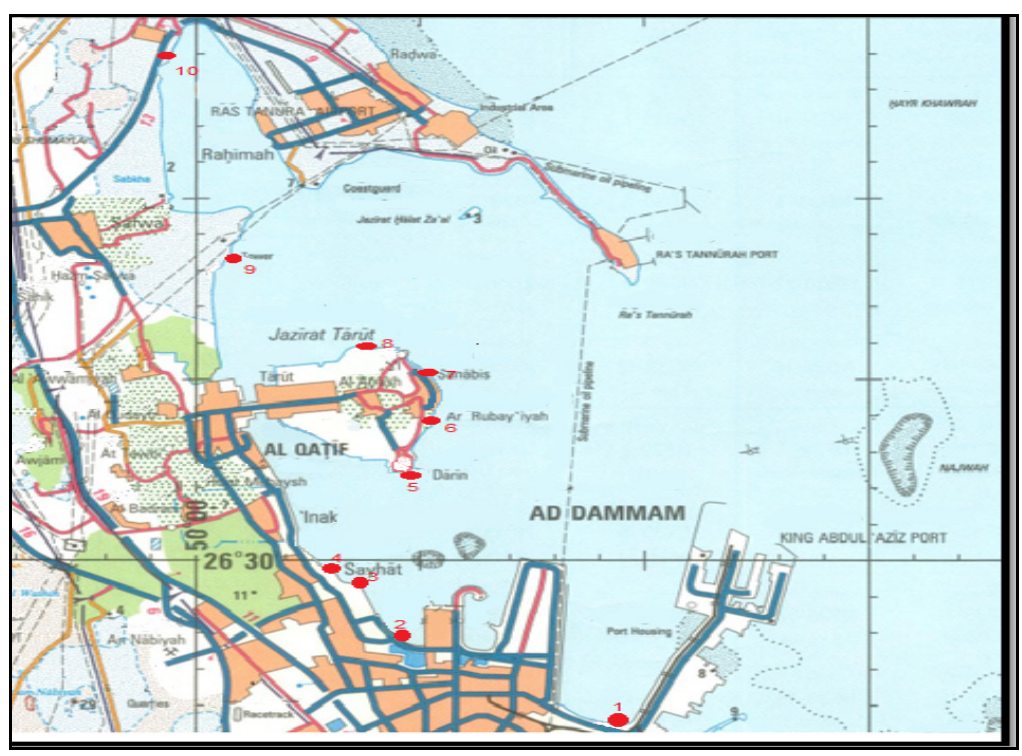

Figure 2. Map of the General Directorate of Military Survey (Modified by the Researcher)

Table 1. GPS points of the study locations

\begin{tabular}{|c|c|c|}
\hline Sites & \multicolumn{2}{|c|}{ GPS } \\
\hline Site1: Dammam Port & $\mathrm{N} 26^{\circ} 25.400^{\prime}$ & E $050^{\circ} 09.196^{\prime}$ \\
\hline Site2: Dammam & N $26^{\circ} 27.957^{\prime}$ & $\mathrm{E} 050^{\circ} 04.376^{\prime}$ \\
\hline Site3: Syhat Road & 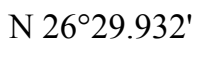 & $\mathrm{E} 050^{\circ} 02.467^{\prime}$ \\
\hline Site4: Syhat & N $26^{\circ} 30.335^{\prime}$ & $\mathrm{E} 050^{\circ} 02.519^{\prime}$ \\
\hline Site5: Darin & $\mathrm{N} 26^{\circ} 33.025^{\prime}$ & $\mathrm{E} 050^{\circ} 04.685^{\prime}$ \\
\hline Site6: Rabiayah & N 26 $33.025^{\prime}$ & $\mathrm{E} 050^{\circ} 04.685^{\prime}$ \\
\hline Site7: Snabis & 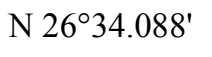 & $\mathrm{E} 050^{\circ} 05.307^{\prime}$ \\
\hline Site8: Zor Forest & $\mathrm{N} 26^{\circ} 35.855^{\prime}$ & $\mathrm{E} 050^{\circ} 03.832^{\prime}$ \\
\hline Site9: Sfwa & 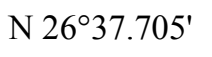 & $\mathrm{E} 050^{\circ} 00.387^{\prime}$ \\
\hline Site10: RasTanurah & N 26요 $44.767^{\prime}$ & E04959.615' \\
\hline
\end{tabular}

Samples collected from water, soil and plants were used to determine the concentrations of eight heavy metals: Boron, Iron, Manganese, Zink, Lead, Nickel, Cadimum and Cupper. The water samples were collected following (Reeve, 2002), three samples were collected from each of the 10 sites in $250 \mathrm{ml}$ polyethylene container, and acidified (by adding $2 \mathrm{ml} \mathrm{Hcl}$ in 1 litter water) to prevent absorption of heavy metals on the sides of the container. The samples were then transported to the laboratory at $\left(4^{\circ} \mathrm{C}\right)$ and heavy metals were analyzed on the same day, using the inductively coupled plasma-optical emission spectroscopy (Clesceri et al., 1998).

Three Soil samples were semantically collected from surface soil $(0-10 \mathrm{~cm})$ and $(10-30 \mathrm{~cm})$ deep soil, at all locations and processed following 1:5 soil to water extraction method (Kalra et al., 1991). The heavy metals were determined by Inductively Coupled Plasma - Mass Spectrometer, following (Jones, 2001).

Three Mangrove (Shoot) samples were collected randomly from all locations during the same period, and dried in electrical oven. The dry ashing protocol was used as it is simple, non-hazardous and less expensive as compared with wet digestion (Ryan et al., 2007). The heavy metals contents were determined through Inductively Coupled Plasma - Mass Spectrometer, by following (AOAC, 1998) protocol. The heavy metals were quantified in ppm, while three samples were analyzed for each parameter.

The data obtained was subjected to statistical tests (T-test) using the software SPSS version 15 (SPSS Inc., Chicago, USA). 


\section{Results}

Grey mangrove vegetation inhabiting 10 sites at Tarut Bay i.e. Dammam Port, Dammam, Syhat Road, Syhat, Darin, Rabiayah, Snabis, Zor Forest, Sfwa and Ras Tanurah were studied for heavy metal accumulation. Of these 10 sites, Ras Tanura registered the highest levels of the total heavy metals $(0.76 \mathrm{ppm})$, while the lowest levels of heavy metals were recorded for Syhat Road, Zor Forest and Dammam. The presence of heavy metals from highest to lowest was as follows: Ras Tanurah $\rightarrow$ Rabiayah $\rightarrow$ Darin $\rightarrow$ Sfwa $\rightarrow$ Dammam Port $\rightarrow$ Syhat $\rightarrow$ Snabis $\rightarrow$ Syhat Road $\rightarrow$ Zor Forest $\rightarrow$ Dammam.

Water samples analyzed for heavy metal accumulation showed that $\mathrm{B}$ and $\mathrm{Pb}$ were present in all samples, while $\mathrm{Cd}$ element was absent $<0.001$, as shown in Table 2 and Figure 3. It was observed that $\mathrm{Pb}$ and $\mathrm{Mn}$ contents in the water ranged from $0.101-0.033 \mathrm{ppm}$ and $0.027-0.013 \mathrm{ppm}$ respectively. The heavy metals were found present in the following sequence, as $\mathrm{B}$ was the most abundant element followed by $\mathrm{Pb}, \mathrm{Fe}, \mathrm{Mn}, \mathrm{Zn}, \mathrm{Cu}, \mathrm{Ni}$ and $\mathrm{Cd}$ respectively.

Table 2. Variations in heavy metal contents (PPM) in Water at ten Sites in the study area

\begin{tabular}{|c|c|c|c|c|c|c|c|c|c|}
\hline City & $\mathrm{Cd}$ & $\mathrm{Cu}$ & $\mathrm{Ni}$ & $\mathrm{Pb}$ & $\mathrm{Zn}$ & $\mathrm{Fe}$ & $\mathrm{Mn}$ & B & Geometric \\
\hline \multirow[t]{2}{*}{ Dammam Port } & $<0.001$ & 0.0023 & $<0.001$ & 0.1007 & 0.0053 & 0.034 & 0.0037 & 0.703 & 1.04 \\
\hline & \pm 0.0000 & \pm 0.0014 & \pm 0.0000 & \pm 0.0052 & \pm 0.0063 & \pm 0.0371 & \pm 0.0052 & \pm 0.1203 & \\
\hline \multirow[t]{2}{*}{ Dammam } & $<0.001$ & 0.0063 & 0.0017 & 0.033 & 0.009 & 0.0157 & 0.0077 & 0.19 & 2.7 \\
\hline & \pm 0.0000 & \pm 0.0038 & \pm 0.0014 & \pm 0.0329 & \pm 0.0174 & \pm 0.0207 & \pm 0.0076 & \pm 0.0878 & \\
\hline \multirow[t]{2}{*}{ Syhat Road } & $<0.001$ & 0.008 & 0.001 & 0.05 & 0.0033 & 0.0443 & 0.017 & 0.303 & 5.48 \\
\hline & \pm 0.0000 & \pm 0.0090 & \pm 0.0000 & \pm 0.0086 & \pm 0.0057 & \pm 0.0509 & \pm 0.0086 & \pm 0.1818 & \\
\hline \multirow[t]{2}{*}{ Syhat } & $<0.001$ & 0.004 & $<0.001$ & 0.088 & 0.0053 & 0.0777 & 0.007 & 0.6273 & 2.52 \\
\hline & \pm 0.0000 & \pm 0.0043 & \pm 0.0000 & \pm 0.0155 & \pm 0.0029 & \pm 0.1707 & \pm 0.0194 & \pm 0.0382 & \\
\hline \multirow[t]{2}{*}{ Darin } & $<0.001$ & 0.004 & $<0.001$ & 0.094 & 0.0057 & 0.1017 & 0.002 & 0.6723 & 1.71 \\
\hline & \pm 0.0000 & \pm 0.0025 & \pm 0.0000 & \pm 0.0197 & \pm 0.0029 & \pm 0.2584 & \pm 0.0025 & \pm 0.0488 & \\
\hline \multirow[t]{2}{*}{ Rabiayah } & $<0.001$ & 0.0047 & $<0.001$ & 0.1007 & 0.0047 & 0.0867 & 0.0013 & 0.7233 & 1.34 \\
\hline & \pm 0.0000 & \pm 0.0029 & \pm 0.0000 & \pm 0.0080 & \pm 0.0029 & \pm 0.2080 & \pm 0.0029 & \pm 0.1174 & \\
\hline \multirow[t]{2}{*}{ Snabis } & $<0.001$ & 0.0033 & 0.001 & 0.0633 & 0.0063 & 0.1163 & 0.027 & 0.5763 & 1.54 \\
\hline & \pm 0.0000 & \pm 0.0029 & \pm 0.0000 & \pm 0.0396 & \pm 0.0125 & \pm 0.3618 & \pm 0.0172 & \pm 0.1329 & \\
\hline \multirow[t]{2}{*}{ Zor Forest } & $<0.001$ & 0.0023 & $<0.001$ & 0.0523 & 0.001 & 0.0567 & 0.0027 & 0.2997 & 2.34 \\
\hline & \pm 0.0000 & \pm 0.0014 & \pm 0.0000 & \pm 0.0150 & \pm 0.0000 & \pm 0.1837 & \pm 0.0029 & \pm 0.0160 & \\
\hline \multirow[t]{2}{*}{ Sfwa } & $<0.001$ & 0.0033 & $<0.001$ & 0.0907 & 0.0047 & 0.07 & 0.002 & 0.6813 & 1.15 \\
\hline & \pm 0.0000 & \pm 0.0014 & \pm 0.0000 & \pm 0.0201 & \pm 0.0029 & \pm 0.0386 & \pm 0.0000 & \pm 0.0845 & \\
\hline \multirow[t]{2}{*}{ RasTanurah } & $<0.001$ & 0.0043 & $<0.001$ & 0.101 & 0.0063 & 0.1433 & 0.002 & 0.761 & 2.44 \\
\hline & \pm 0.0000 & \pm 0.0029 & \pm 0.0000 & \pm 0.0282 & \pm 0.0029 & \pm 0.0117 & \pm 0.0000 & \pm 0.1323 & \\
\hline Total of Mean/Ion & $<0.001$ & 0.0427 & 0.0037 & 0.7737 & 0.0517 & 0.7463 & 0.0723 & 5.5373 & \\
\hline
\end{tabular}



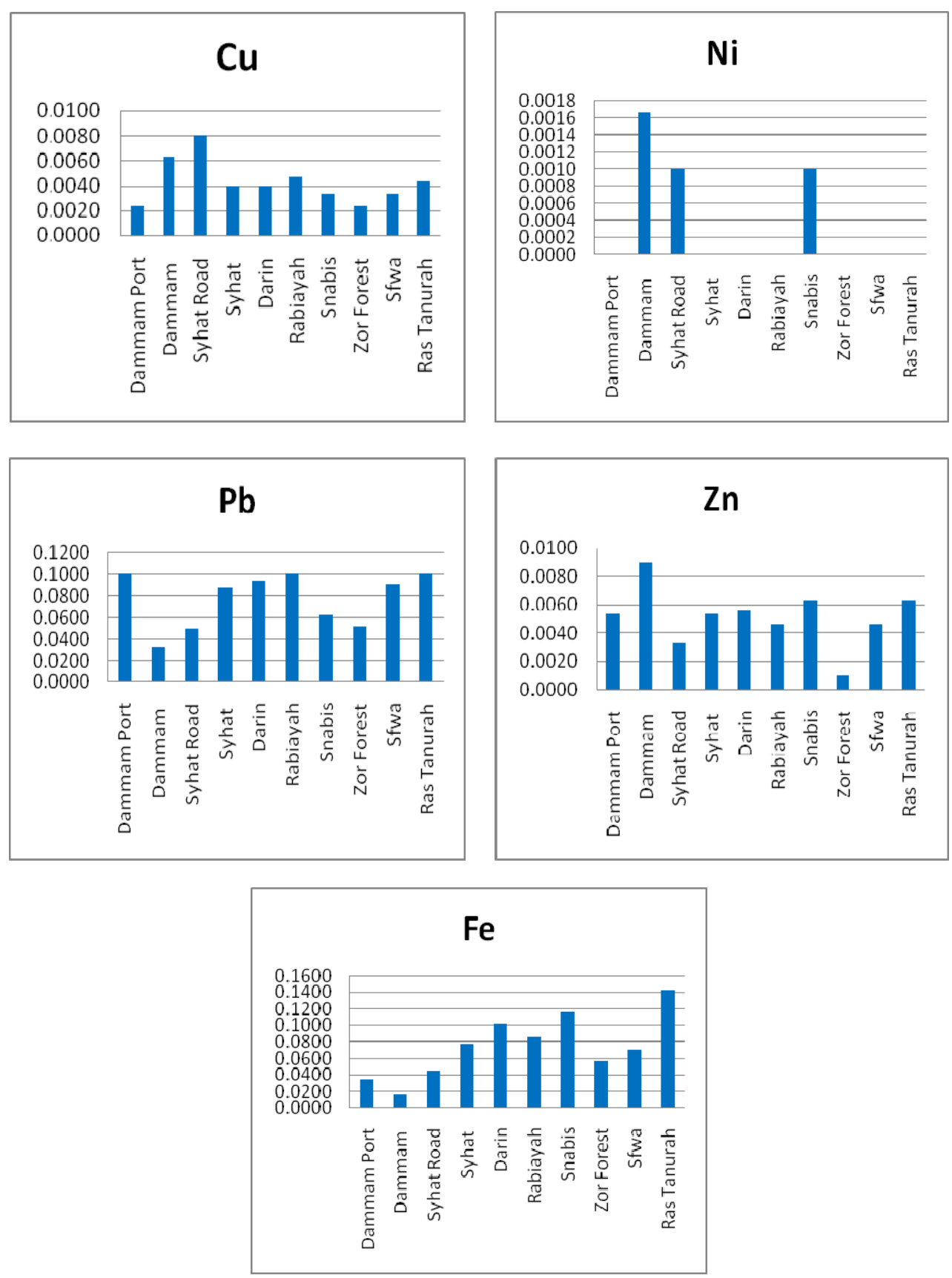

Figure 3. Heavy Metals In Water (PPM)

In soil samples, B and Fe elements were present in higher contents as their concentration reached to $2.250 \mathrm{ppm}$ in soil surface layer at Zor Forest, while lowest contents (1.02 ppm) of B and Fe were recorded for deep layer of soil at Dammam. The elements $\mathrm{Cd}$ and $\mathrm{Cu}$ were present in negligible quantities in all soil samples $(<0.001)$, as shown in Table 3 and Figure 4. The overall contents from highest to lowest al all sites were as follows: $\mathrm{B} \rightarrow \mathrm{Ni} \rightarrow \mathrm{Zn} \rightarrow \mathrm{Mn} \rightarrow \mathrm{Pb} \rightarrow \mathrm{Fe} \rightarrow \mathrm{Cd}=\mathrm{Cu}$. It was also observed that the contents of heavy metals greatly varied in surface and deep soil. We recorded that the mean concentrations of heavy metals in surface soil of 10 sites from highest to lowest were as follows: Zor $\quad$ Forest $\rightarrow$ Dammam Port $\rightarrow$ Snabis $\rightarrow$ SyhatRoad $\rightarrow$ Rabiayah $\rightarrow$ Darin $\rightarrow$ Syhat $\rightarrow$ Dammam $\rightarrow$ Ras Tanurah. On the other hand, the mean concentrations of heavy metals in deep soil of all these sites decreased as follows: Zor Forest $\rightarrow$ Rabiayah $\rightarrow$ Ras Tanurah $\rightarrow$ Syhat Road $\rightarrow$ Syhat $\rightarrow$ Sfwa $\rightarrow$ Dammam Port $\rightarrow$ Snabis $\rightarrow$ Darin $\rightarrow$ Dammam (Table $3 \&$ Figure 4). 
Table 3. Variations in heavy metal contents in PPM Soil Surface S: Depth, D.

\begin{tabular}{|c|c|c|c|c|c|c|c|c|c|}
\hline City & $\mathrm{Cd}$ & $\mathrm{Cu}$ & $\mathrm{Ni}$ & $\mathrm{Pb}$ & $\mathrm{Zn}$ & $\mathrm{Fe}$ & $\mathrm{Mn}$ & $\mathrm{B}$ & Geometric \\
\hline \multirow[t]{2}{*}{ Dammam Port S } & $<0.001$ & $<0.001$ & 0.035 & $<0.001$ & $<0.001$ & $<1$ & 0.0063 & 1.92 & 0.0206 \\
\hline & \pm 0.0000 & \pm 0.0000 & \pm 0.0025 & \pm 0.0000 & \pm 0.0000 & \pm 0.0000 & \pm 0.0087 & \pm 0.2687 & \\
\hline \multirow[t]{2}{*}{ Dammam Port D } & $<0.001$ & $<0.001$ & 0.0127 & $<0.001$ & 0.038 & $<1$ & 0.007 & 1.0417 & 0.0019 \\
\hline & \pm 0.0000 & \pm 0.0000 & \pm 0.0117 & \pm 0.0000 & \pm 0.0752 & \pm 0.0000 & \pm 0.0066 & \pm 0.0808 & \\
\hline \multirow[t]{2}{*}{ Dammam S } & $<0.001$ & $<0.001$ & 0.0097 & $<0.001$ & 0.005 & $<1$ & 0.0027 & 1.2337 & 0.0004 \\
\hline & \pm 0.0000 & \pm 0.0000 & \pm 0.0038 & \pm 0.0000 & \pm 0.0000 & \pm 0.0000 & \pm 0.0029 & \pm 0.4829 & \\
\hline \multirow[t]{2}{*}{ Dammam D } & $<0.001$ & $<0.001$ & 0.004 & $<0.001$ & $<0.001$ & $<1$ & 0.001 & 1.0203 & 0.0020 \\
\hline & \pm 0.0000 & \pm 0.0000 & \pm 0.0025 & \pm 0.0000 & \pm 0.0000 & \pm 0.0000 & \pm 0.0000 & \pm 0.0236 & \\
\hline \multirow[t]{2}{*}{ Syhat Road S } & $<0.001$ & $<0.001$ & 0.009 & $<0.001$ & $<0.001$ & $<1$ & 0.001 & 1.536 & 0.0037 \\
\hline & \pm 0.0000 & \pm 0.0000 & \pm 0.0043 & \pm 0.0000 & \pm 0.0000 & \pm 0.0000 & \pm 0.0000 & \pm 0.1615 & \\
\hline \multirow[t]{2}{*}{ Syhat Road D } & $<0.001$ & $<0.001$ & 0.0053 & $<0.001$ & $<0.001$ & $<1$ & 0.0017 & 1.2527 & 0.0034 \\
\hline & \pm 0.0000 & \pm 0.0000 & \pm 0.0029 & \pm 0.0000 & \pm 0.0000 & \pm 0.0000 & \pm 0.0029 & \pm 0.4711 & \\
\hline \multirow[t]{2}{*}{ Syhat S } & $<0.001$ & $<0.001$ & 0.0063 & 0.003 & 0.074 & $<1$ & 0.0027 & 1.2917 & 0.0001 \\
\hline & \pm 0.0000 & \pm 0.0000 & \pm 0.0052 & \pm 0.0000 & \pm 0.0248 & \pm 0.0000 & \pm 0.0029 & \pm 0.3652 & \\
\hline \multirow[t]{2}{*}{ Syhat D } & $<0.001$ & $<0.001$ & 0.0073 & 0.006 & $<0.001$ & $<1$ & 0.0023 & 1.2183 & 0.0004 \\
\hline & \pm 0.0000 & \pm 0.0000 & \pm 0.0143 & \pm 0.0000 & \pm 0.0000 & \pm 0.0000 & \pm 0.0038 & \pm 0.1686 & \\
\hline \multirow[t]{2}{*}{ Darin S } & $<0.001$ & $<0.001$ & 0.0037 & $<0.001$ & 0.001 & $<1$ & 0.001 & 1.4363 & 0.0001 \\
\hline & \pm 0.0000 & \pm 0.0000 & \pm 0.0014 & \pm 0.0000 & \pm 0.0000 & \pm 0.0000 & \pm 0.0000 & \pm 0.5234 & \\
\hline \multirow[t]{2}{*}{ Darin D } & $<0.001$ & $<0.001$ & 0.0037 & $<0.001$ & $<0.001$ & $<1$ & 0.001 & 1.0223 & 0.0019 \\
\hline & \pm 0.0000 & \pm 0.0000 & \pm 0.0014 & \pm 0.0000 & \pm 0.0000 & \pm 0.0000 & \pm 0.0000 & \pm 0.1941 & \\
\hline \multirow[t]{2}{*}{ Rabiayah S } & $<0.001$ & $<0.001$ & 0.0037 & $<0.001$ & $<0.001$ & $<1$ & 0.001 & 1.46 & 0.0023 \\
\hline & \pm 0.0000 & \pm 0.0000 & \pm 0.0014 & \pm 0.0000 & \pm 0.0000 & \pm 0.0000 & \pm 0.0000 & \pm 0.0248 & \\
\hline \multirow[t]{2}{*}{ Rabiayah D } & $<0.001$ & $<0.001$ & 0.0043 & $<0.001$ & $<0.001$ & $<1$ & 0.0013 & 1.4167 & 0.0028 \\
\hline & \pm 0.0000 & \pm 0.0000 & \pm 0.0014 & \pm 0.0000 & \pm 0.0000 & \pm 0.0000 & \pm 0.0014 & \pm 0.4701 & \\
\hline \multirow[t]{2}{*}{ Snabis $\mathrm{S}$} & $<0.001$ & $<0.001$ & 0.0077 & $<0.001$ & 0.001 & $<1$ & 0.0017 & 1.6267 & 0.0001 \\
\hline & \pm 0.0000 & \pm 0.0000 & \pm 0.0014 & \pm 0.0000 & \pm 0.0000 & \pm 0.0000 & \pm 0.0014 & \pm 0.1034 & \\
\hline \multirow[t]{2}{*}{ Snabis D } & $<0.001$ & $<0.001$ & 0.0053 & $<0.001$ & $<0.001$ & $<1$ & 0.0017 & 1.023 & 0.0030 \\
\hline & \pm 0.0000 & \pm 0.0000 & \pm 0.0029 & \pm 0.0000 & \pm 0.0000 & \pm 0.0000 & \pm 0.0014 & \pm 0.3485 & \\
\hline \multirow[t]{2}{*}{ Zor Forest S } & $<0.001$ & $<0.001$ & 0.0487 & $<0.001$ & $<0.001$ & $<1$ & 0.0013 & 2.25 & 0.0119 \\
\hline & \pm 0.0000 & \pm 0.0000 & \pm 0.0029 & 0 & \pm 0.0000 & \pm 0.0000 & \pm 0.0014 & \pm 0.0861 & \\
\hline \multirow[t]{2}{*}{ Zor Forest D } & $<0.001$ & $<0.001$ & 0.011 & $<0.001$ & $<0.001$ & $<1$ & 0.0013 & 1.5523 & 0.0047 \\
\hline & \pm 0.0000 & \pm 0.0000 & \pm 0.0086 & \pm 0.0000 & \pm 0.0000 & \pm 0.0000 & \pm 0.0014 & \pm 0.0183 & \\
\hline \multirow[t]{2}{*}{ Sfwa S } & $<0.001$ & $<0.001$ & 0.0047 & 0.002 & $<0.001$ & $<1$ & 0.0013 & 1.2973 & 0.0001 \\
\hline & \pm 0.0000 & \pm 0.0000 & \pm 0.0029 & \pm 0.0000 & \pm 0.0000 & \pm 0.0000 & \pm 0.0014 & \pm 0.4386 & \\
\hline \multirow[t]{2}{*}{ Sfwa D } & $<0.001$ & $<0.001$ & 0.004 & $<0.001$ & $<0.001$ & $<1$ & 0.001 & 1.182 & 0.0022 \\
\hline & \pm 0.0000 & \pm 0.0000 & \pm 0.0025 & \pm 0.0000 & \pm 0.0000 & \pm 0.0000 & \pm 0.0000 & \pm 0.1612 & \\
\hline \multirow[t]{2}{*}{ RasTanurah S } & $<0.001$ & $<0.001$ & 0.003 & $<0.001$ & 0.0267 & $<1$ & 0.0013 & 1.2193 & 0.0004 \\
\hline & \pm 0.0000 & \pm 0.0000 & \pm 0.0000 & \pm 0.0000 & \pm 0.0954 & \pm 0.0000 & \pm 0.0014 & \pm 0.3604 & \\
\hline \multirow[t]{2}{*}{ RasTanurah D } & $<0.001$ & $<0.001$ & 0.0043 & $<0.001$ & $<0.001$ & $<1$ & 0.0017 & 1.2903 & 0.0031 \\
\hline & \pm 0.0000 & \pm 0.0000 & \pm 0.0014 & \pm 0.0000 & \pm 0.0000 & \pm 0.0000 & \pm 0.0029 & \pm 0.2486 & \\
\hline Total of Mean/Ion & $<0.001$ & $<0.001$ & 0.193 & $<0.011$ & $<0.145$ & $<1$ & 0.04 & 27.291 & \\
\hline
\end{tabular}



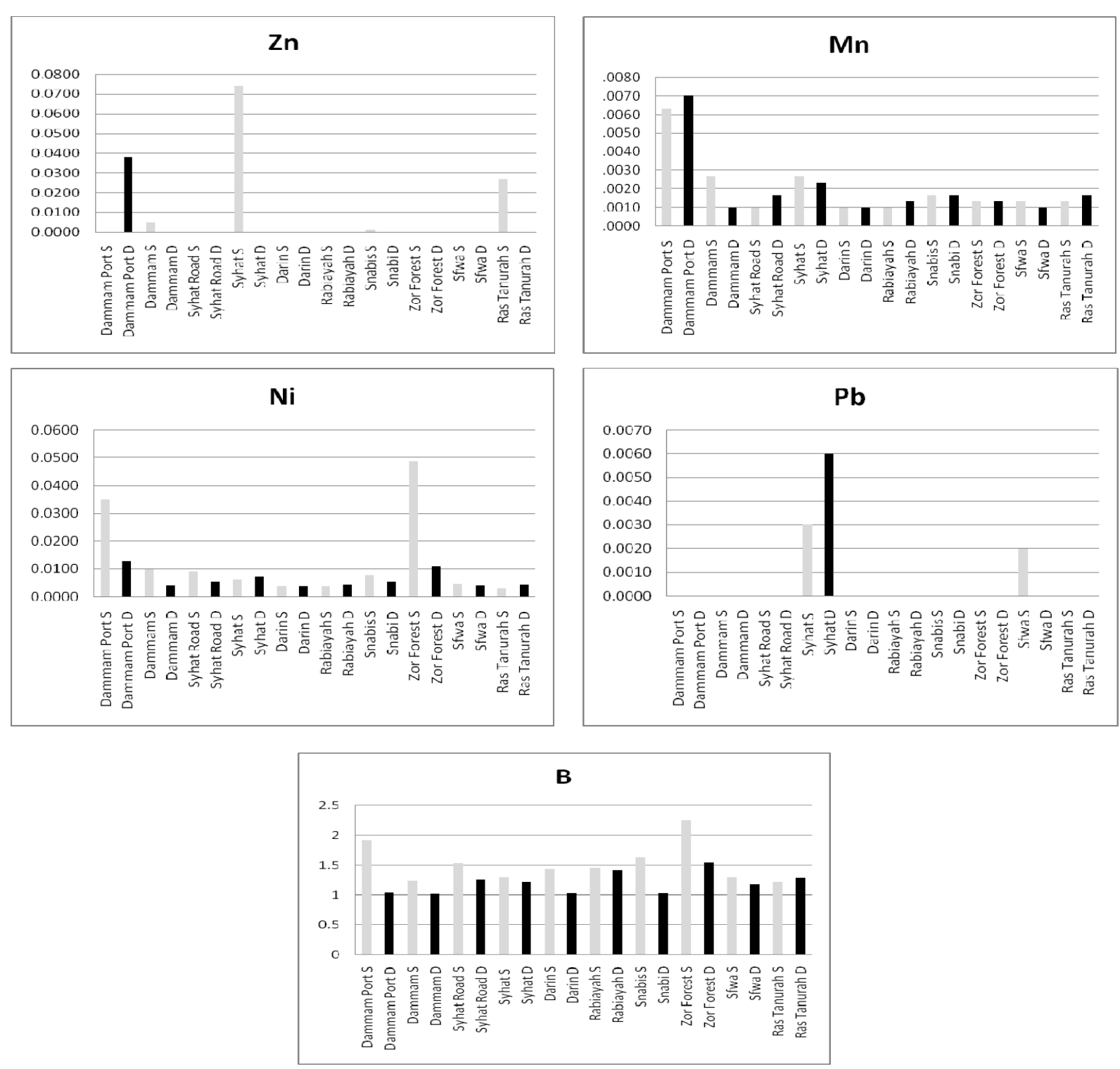

Figure 4. Heavy Metals In Soil (PPM)

The analysis of grey mangrove samples for heavy metals accumulation showed that $\mathrm{Cu}$ and $\mathrm{Fe}$ elements were present in highest concentrations in Ras Tanurah site, where a heavy metal concentration have reached to 22.67 ppm, while $\mathrm{Cd}$ was the least accumulated element in grey mangroves. An overall concentration of various elements from most abundant to least in plant samples were as follows: $\mathrm{Cu} \rightarrow \mathrm{Fe} \rightarrow \mathrm{Mn} \rightarrow \mathrm{Zn} \rightarrow \mathrm{B} \rightarrow \mathrm{Ni} \rightarrow \mathrm{Pb} \rightarrow \mathrm{Cd}$. It was observed that Ras Tanurah was the most polluted site with maximum heavy metals presence, and the accumulation of heavy metals in plant samples of various sites decreased as follows: Ras Tanurah $\rightarrow$ Syhat Road $\rightarrow$ Snabis $\rightarrow$ Darin $\rightarrow$ Sfwa $\rightarrow$ Dammam $\rightarrow$ Zor Forest $\rightarrow$ Syhat $\rightarrow$ Dammam Port $\rightarrow$ Rabiayah (Table 4 \& Figure 5) 
Table 4. Variations in heavy metal contents (PPM) in Avicennia marina

\begin{tabular}{llllllllll}
\hline City & $\mathrm{Cd}$ & $\mathrm{Cu}$ & $\mathrm{Ni}$ & $\mathrm{Pb}$ & $\mathrm{Zn}$ & $\mathrm{Fe}$ & $\mathrm{Mn}$ & $\mathrm{B}$ & Geometric \\
\hline Dammam Port & 0.001 & 5.14 & 0.037 & 0.0183 & 0.4723 & 5.67 & 0.377 & 0.4143 & 0.0012 \\
& \pm 0.0000 & \pm 0.00 & \pm 0.0366 & \pm 0.0072 & \pm 0.2214 & \pm 11.74 & \pm 0.1302 & \pm 0.1093 & \\
Dammam & 0.0013 & 8.67 & 0.054 & 0.0297 & 0.475 & 6.67 & 0.5373 & 0.1957 & 0.0025 \\
& \pm 0.0014 & \pm 0.00 & \pm 0.0474 & \pm 0.0288 & \pm 0.2578 & \pm 3.79 & \pm 0.1891 & \pm 0.0273 & \\
Syhat Road & 0.002 & 10.07 & 0.0637 & 0.019 & 0.468 & 14.33 & 0.631 & 0.3753 & 0.0062 \\
& \pm 0.0025 & \pm 0.00 & \pm 0.0829 & \pm 0.0212 & \pm 0.3493 & \pm 18.81 & \pm 0.3861 & \pm 0.4253 & \\
Syhat & 0.0013 & 9.73 & 0.019 & 0.0073 & 0.2723 & 2.33 & 0.251 & 0.3567 & 0.0003 \\
& \pm 0.0014 & \pm 0.00 & \pm 0.0151 & \pm 0.0038 & \pm 0.1333 & \pm 1.43 & \pm 0.0630 & \pm 0.2736 & \\
Darin & 0.001 & 15.8 & 0.0233 & 0.0083 & 0.3037 & 3.67 & 0.3393 & 0.3393 & 0.0006 \\
& \pm 0.0000 & \pm 0.00 & \pm 0.0176 & \pm 0.0052 & \pm 0.1653 & \pm 5.17 & \pm 0.3066 & \pm 0.2123 & \\
Rabiayah & 0.0017 & 5.27 & 0.032 & 0.01 & 0.3557 & 5 & 0.445 & 0.3193 & 0.0009 \\
& 0.0029 & \pm 0.00 & \pm 0.0197 & \pm 0.0000 & \pm 0.3881 & \pm 4.97 & \pm 0.2644 & \pm 0.4038 & \\
Snabis & 0.001 & 11 & 0.0497 & 0.0137 & 0.4093 & 10.33 & 0.5103 & 0.3207 & 0.0023 \\
& \pm 0.0000 & \pm 0.00 & \pm 0.0426 & \pm 0.0072 & \pm 0.3642 & \pm 8.72 & \pm 0.3857 & \pm 0.1389 & \\
Zor Forest & 0.0013 & 7.07 & 0.0427 & 0.0127 & 0.2013 & 5.67 & 0.635 & 0.3873 & 0.0012 \\
& \pm 0.0014 & \pm 0.00 & \pm 0.0462 & \pm 0.0268 & \pm 0.2531 & \pm 6.25 & \pm 0.1893 & \pm 0.2212 & \\
Sfwa & 0.0013 & 11.8 & 0.035 & 0.0103 & 0.35 & 4.33 & 0.4573 & 0.3647 & 0.0012 \\
& \pm 0.0014 & \pm 0.00 & \pm 0.0215 & \pm 0.0057 & \pm 0.2226 & \pm 2.87 & \pm 0.5278 & \pm 0.1271 & \\
RasTanurah & 0.0017 & 22.67 & 0.039 & 0.0153 & 0.314 & 5 & 0.8993 & 0.3363 & 0.0033 \\
& \pm 0.0014 & \pm 0.00 & \pm 0.0263 & \pm 0.0143 & \pm 0.2685 & \pm 2.48 & \pm 0.2906 & \pm 0.0983 & \\
Total & 0.0137 & 107.22 & 0.3953 & 0.1447 & 3.6217 & 63 & 5.0827 & 3.4097 & \\
\hline
\end{tabular}



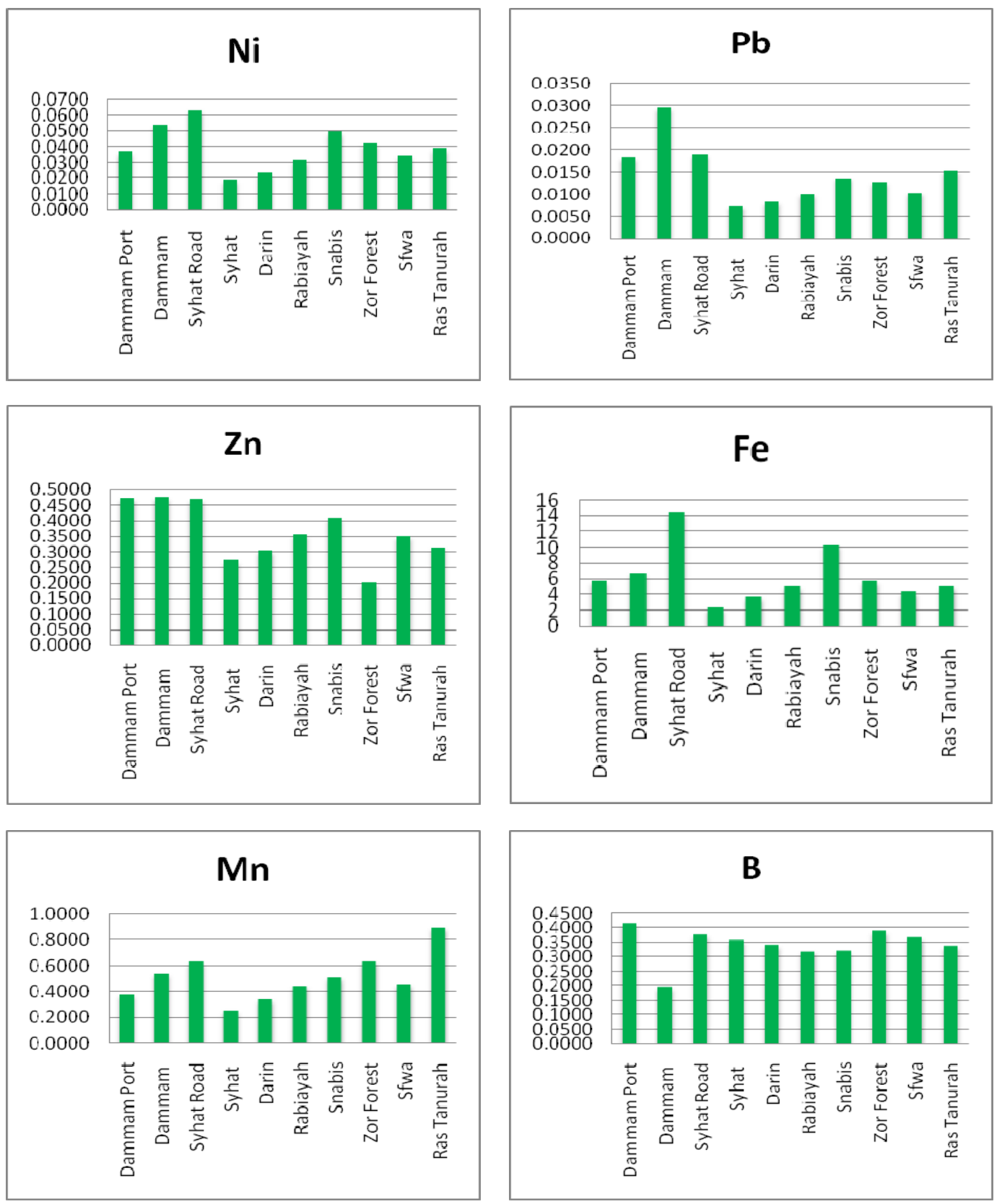

Figure 5. Heavy Metals In Plant (PPM)

\section{Discussion}

Heavy metal pollution of the biosphere has hugely accelerated since the beginning of the industrial revolution (Nriagu, 1979). All over the world, industrialization and urbanization has accelerated the problem of heavy metal contamination. Heavy metals are metals with specific gravity greater than $5 \mathrm{~g} / \mathrm{cm}^{3}$ (Nies, 1999). Lead, mercury, arsenic, and cadmium ranked as first, second, third, and sixth hazards on the list from US Agency for Toxic Substances and Disease Registry (ATSDR) that lists all hazards present in toxic waste sites according to their prevalence and the severity of their toxicity. These days, the problem of heavy metal contamination is a matter of serious concern on a local, regional, and global scale (Rai, 2008). Plants absorb heavy metals through their roots, or even via their stems and leaves, and accumulate them in their tissues plus Plants take up elements selectively, which subsequently move through the biogeochemical cycle and are transported to the coastal waters (Ramos et al., 2006).

In this study, noticeable results of heavy metals accumulation in water samples showed that B element was abundant at all locations and usually elevated levels of B in surface waters often occur within the industrial and 
urban areas, while $\mathrm{Cd}$ element was rare in all ten locations $(<0.001)$. Our current findings confirm the previous report of (Kar et al., 2008), which stated that a total of 96 surface water samples collected from Ganga river in West Bengal during 2004-05: $\mathrm{Fe}, \mathrm{Mn}, \mathrm{Zn}, \mathrm{Ni}, \mathrm{Cr}$ and $\mathrm{Pb}$ were detected in more than $92 \%$ of the samples. Another study observed that B concentration of the Seydi Stream in Turkey was much higher than the Turkish Environmental standard (Emiroglu et al., 2010).

In soil samples, higher contents of $\mathrm{B}$ were found, while $\mathrm{Cd}$ and $\mathrm{Cu}$ elements were present in negligible quantities $(<0.001)$. Similarly, earlier studies showed that B content was much higher in soils of dry and semi-dry areas as compared to wet lands (Mengel \& Kirkby, 1979). Chemical analysis of soil samples showed that lack of Cu can be expected in the basic and limestone soils and the soils usually scattered in dry and semi-dry regions, like those of Saudi Arabia (Modaihsh et al., 2005). On the other hand, lack of $\mathrm{Cu}, \mathrm{Fe}, \mathrm{Mn}$ and $\mathrm{Zn}$ in alkaline soils has been previously reported (Noggle \& Fritz, 1976).

In plant samples, $\mathrm{Cu}$ element was abundant while $\mathrm{Cd}$ was the least accumulated element. Low contents of $\mathrm{Cd}$ may be due to its quite low and slow acropetal translocation in plants as reported by (Wolterbeek \& Van, 2002). In grey mangrove, the accumulative partitioning of heavy metals demonstrated that under field conditions, the higher $\mathrm{Cu}$ and $\mathrm{Pb}$ elements were accumulated in root tissues as compared to the surrounding sediment levels. We observed that the mean heavy metal concentration in plant samples were significantly higher than water and soil samples. It clearly demonstrated the capacity of grey mangrove as a vital heavy metal accumulating plant. (Usman et al., 2013) also found out that A.marina of Farasan Island west Saudia Arabia can be a potential accumulator of $\mathrm{Cu}$ in aboveground parts (Usman et al., 2013). Also a Higher accumulation of $\mathrm{Cu}$ and $\mathrm{Pb}$ in roots and leaves of Sonneratia caseolar showed that this plant can be used as potential phytoremediation species for selected heavy metals in Malaysian mangrove ecosystem (MacFarine et al., 2003; Nazli \& Hashim, 2010). Previous studies showed that mangrove stands have been widely used as bio-indicators for different types of environmental pollutants including heavy metals, organic pollutants and hydrocarbons It was reported that heavy metal concentrations in leaves of grey mangrove was higher than the bioavailable fraction of metals present in sediments (Sadooni \& El-Kassas, 1999).

\section{Conclusion}

Current study showed that grey mangroves absorbed higher quantities of heavy metals from their surroundings, which demonstrate the importance of these plants in cleaning the coastal environments from pollutants. It is thus recommended that grey mangroves vegetation must be prevented from further decay by checking various factors which has caused deforestation of these valuable assets. Also to do more experiments by adding some fertilizers to it and check the possibility of increasing the populations because if deterioration of grey mangroves continues, it will result in the destruction of local ecosystem, erosion of the Tarut Bay, and the coast may become an environmental mess.

\section{References}

A. O. A. C. (1998). Official Methods of Analysis of the Association of Official Chemists. $16^{\text {th }}$ ed. $4^{\text {th }}$ Rev. AOAC INC. Washington, DC., U.S.A.

Adler, A. (2007). Accumulation of elements in Salix and other species used in vegetation filters with focus on wood fuel quality. Uppsala: Dept. of Crop Production Ecology, Swedish University of Agricultural Sciences.

Agoramoorthy, G., Chen, F.-A., \& Hsu, M. J. (2008). Threat of heavy metal pollution in halophytic and mangrove plants of Tamil Nadu, India. Environmental Pollution, 155(2), 320-326. http://dx.doi.org/10.1016/j.envpol.2007.11.011

Ait, A. N., Bernal, M. P., \& Ater, M. (2004). Tolerance and bioaccumulation of cadmium by Phragmites australis grown in the presence of elevated concentrations of cadmium, copper, and zinc. Aquatic Botany, 80(3), 163-176. http://dx.doi.org/10.1016/j.aquabot.2004.08.008

Alayaf, A. (1993). Welcome to Eastern Province of Saudi Arabia. First Tourist Information Guide for the Eastern Province. Al-Khobar : IWA, Information Window Agency.

Al-Farraj, S., El-Gendy, A., Alyahya, H., \& El-Hedeny, M. (2011). Heavy metals accumulation in the mantle of the common cuttlefish Sepia pharaonis from the Arabian Gulf. Aust. J. Basic Applied Sci, 5, 897-905.

Al-Khateeb, S. A., \& Leilan, A. A. (2005). Heavy Metals Accumulation in the Natural Vegetation of Eastern Province of Saudi Arabia. Journal of Biological Sciences, 5(6), 707-712. http://dx.doi.org/10.3923/jbs.2005.707.712 
Al-Sulami, S., Al-Hassan, A. M., Daili, M., Mohd, N. K., Fita, N. A., Ibrahim, M. M., \& Hassan, M. A. (2002). Study On The Distribution Of Toxic Heavy Metals In The Fishes, Sediments \& Waters Of Arabian Gulf Along The Eastern Coast Of Saudi Arabia.

Al-Taisan, W. A. (2009). Suitability of Using Phragmites australis and Tamarix aphylla as Vegetation Filters in Industrial Areas. American Journal of Environmental Sciences, 5(6), 740-747. http://dx.doi.org/10.3844/ajessp.2009.740.747

Baker, A. J. M., McGrath, S. P., Sidoli, C. M. D., \& Reeves, R. D. (1994). The possibility of in situ heavy metal decontamination of polluted soils using crops of metal-accumulating plants. Resources, Conservation and Recycling, 11, 41-49. http://dx.doi.org/10.1016/0921-3449(94)90077-9

Bejarano, A. C., \& Michel, J. (2010). Large-scale risk assessment of polycyclic aromatic hydrocarbons in shoreline sediments from Saudi Arabia: Environmental legacy after twelve years of the Gulf war oil spill. Environmental Pollution, 158(5), 1561-1569. http://dx.doi.org/10.1016/j.envpol.2009.12.019

Clesceri, L. S., Greenberg, A. E., \& Eaton, A. D. (1998). Standard methods for the examination of water and wastewater (20th ed.). Washington: APHA American Public Health Association.

Czudek, R. (2006). Wildlife issues and development prospects in West and Central Asia, Thematic study for the Forestry Outlook Study for Africa. The wildlife management working paper 9, of Food and Agriculture Organization of the United Nations (p. 71).

Danish, E. Y. (2010). Ecological impact from chemicals in the Arabian Gulf due to Gulf oil spill. Water and Environment Journal, 24(1), 65-73. http://dx.doi.org/10.1111/j.1747-6593.2008.00145.x

Dushenkov, V., Kumar, P. B. A. N., Motto, H., \& Raskin, I. (1995). Rhizofiltration: The Use of Plants to Remove Heavy Metals from Aqueous Streams. Environmental Science \& Technology, 29(5), 1239-1245. $\mathrm{http}: / / \mathrm{dx}$.doi.org/10.1021/es00005a015

Emiroglu, O., Arslan, N., Aksan, S., Ruzgar, M., \& Cicek, A. (2010). Boron concentration in water, sediment and different organisms around large borate deposits of Turkey. Bulletin of Environmental Contamination and Toxicology, 84(4), 427-431. http://dx.doi.org/10.1007/s00128-010-9961-8

GESAMP. (2007). IMO/FAO/UNESCO-IOC/WMO/WHO/IAEA/UN/UNEP Joint Group of Experts on the Scientific Aspects of Marine Environmental Protection. Estimates of oil entering the marine environment from sea-based activities. London: International Maritime Organization.

Gundlach, E. R., McCain, J. C., \& Fadlallah, Y. H. (1993). Distribution of oil along the Saudi Arabian coastline (May/June 1991) as a result of the Gulf War oil spills. Marine Pollution Bulletin, 27, 93-96. http://dx.doi.org/10.1016/0025-326X(93)90012-9

Hashem, A. (2007). Bioremediation of Petroleum Contaminated Soils in the Arabian Gulf Region: A Review. Journal of King Abdulaziz University-Science, 19(1), 81-91. http://dx.doi.org/10.4197/Sci.19-1.7

Hashim, O., AL-Hussaini, M., \& AL-Baz, A. (1995). Signs of Oil Pollution on Fishes in The Arabian Gulf. Journal of King Abdulaziz University-Marine Sciences, 6(1), 79-92. http://dx.doi.org/10.4197/mar.6-1.7

Isaiah, N. K., Poliyaparambil, R. S., Rita, N. K., George, B., \& Viyol, S. (2011). An Assessment of the Accumulation Potential of $\mathrm{Pb}, \mathrm{Zn}$ and $\mathrm{Cd}$ by Avicennia marina (Forssk.) Vierh. in Vamleshwar Mangroves, Gujarat, India. University of Agricultural Sciences and Veterinary Medicine, Cluj-Napoca, Romania.

Jacob, P., \& Al-Muzaini, S. (1995). Marine plants of the Arabian Gulf and effects of oil pollution. Mahasagar, 28(1-2), 83-101.

Jones, J. B. (2001). Laboratory guide for conduction soil test and plane analysis. N.W, Florida: CRC Press LLC.

Kalra, Y. P., Maynard, D. G., \& Northern Forestry Centre (Canada). (1991). Methods manual for forest soil and plant analysis. Edmonton, Alta: Forestry Canada, Northwest Region, Northern Forestry Centre.

Kamal, M., Ghaly, A. E., Mahmoud, N., \& Côté, R. (2004). Phytoaccumulation of heavy metals by aquatic plants. Environment International, 29(8), 1029-39. http://dx.doi.org/10.1016/S0160-4120(03)00091-6

Kar, D., Sur, P., Mandal, S. K., Saha, T., \& Kole, R. K. (2008). Assessment of heavy metal pollution in surface water. International Journal of Environmental Science and Technology, 5(1), 119-124. http://dx.doi.org/10.1007/BF03326004

Kubota, H., \& Takenaka, C. (2003). Field Note: Arabis gemmifera is a Hyperaccumulator of Cd and Zn. International Journal of Phytoremediation, 5(3), 197-201. http://dx.doi.org/10.1080/713779219 
Literathy, P., Khan, N. Y., \& Linden, O. (2002). Oil and Petroleum industry. The Gulf ecosystem: Health and sustainability (pp. 127-156). Leiden: Backhuys.

Loughland, R. A., \& AL-Abdulkader, K. A. (2011). Marine Atlas Western Arabian Gulf, ASaudi Aramco Environmental Protection Publication.

MacFarlane, G. R., \& Burchett, M. D. (2002). Toxicity, growth and accumulation relationships of copper, lead and zinc in the grey mangrove Avicennia marina (Forsk.) Vierh. Marine Environmental Research, 54(1), 65-84. http://dx.doi.org/10.1016/S0141-1136(02)00095-8

MacFarlane, G. R., Koller, C. E., \& Blomberg, S. P. (2007). Accumulation and partitioning of heavy metals in mangroves: A synthesis of field-based studies. Chemosphere, 69(9), 1454-1464. http://dx.doi.org/10.1016/j.chemosphere.2007.04.059

MacFarlane, G. R., Pulkownik, A., \& Burchett, M. D. (2003). Accumulation and distribution of heavy metals in the grey mangrove, Avicennia marina (Forsk.)Vierh.: biological indication potential. Environmental Pollution, 123(1), 139-151. http://dx.doi.org/10.1016/S0269-7491(02)00342-1

Manousaki, E., Kadukova. J., \& Kalogerakis, N. (2007). Excretion of metals by the leaves of plants: A new approach to the phytoremediation of sites contaminated with heavy metals. Proceeding of the 10th International Conference on Environmental Science and Technology, 916-923.

Mengel, K., Kirkby, E. A., \& International Potash Institute. (1979). Principles of plant nutrition (2nd ed.). Bern: International Potash Institute.

Metz, H. C. (1993). Saudi Arabia: A Country Study. Washington: GPO for the Library of Congress.

Modaihsh, S. A., Mahjoub, M. O., Taha, A. A., \& Al-Lhayan, M. M. (2005). Status of Copper in Some Agricultural Regions in the Kingdom of Saudi Arabia. Journal of King Saud University. Agricultural Sciences, 17(1).

Nazli, M. F., \& Hashim, N. R. (2010). Heavy metal concentrations in an important mangrove species, Sonneratia Caseolaris, in Peninsular Malaysia. Environmentasia, 3, 50-55.

Nies, D. H. (1999). Microbial heavy-metals resistance. Appl. Microbial Biotechnol, 51, $730-750$. http://dx.doi.org/10.1007/s002530051457

Noggle, G. R., \& Fritz, G. J. (1976). Introductory plant physiology. Englewood Cliffs, N.J: Prentice-Hall.

Nriagu, J. O. (1979). Global inventory of natural and anthropogenic emission of trace metals to the atomoshere. Nature, 279, 409- 411. http://dx.doi.org/10.1038/279409a0

Parvaresh, H. (2011). Identification of threats on Mangrove forests in Gabrik International Wetland for Sustainable Management. In Paper Presented at International Conference on Biology, Environment and Chemistry. Singapoore.

Pourang, N., Dennis, J. H., \& Ghourchian, H. (2005). Distribution of heavy metals in Penaeus semisulcatus from Persian Gulf and possible role of metallothionein in their redistribution during storage. Environmental Monitoring and Assessment, 100(1-3), 71-88. http://dx.doi.org/10.1007/s10661-005-7061-8

Rai, P. K. (2008). Phytoremediation of $\mathrm{Hg}$ and $\mathrm{Cd}$ from industrial effluents using an aquatic free floating macrophyte Azolla pinnata. Environ. Sci Technol. In press.

Ramos, S. C. A., da, S. A. P., \& de, O. S. R. (2006). Concentration, stock and transport rate of heavy metals in a tropical red mangrove, Natal, Brazil. Marine Chemistry, 99, 2-11. http://dx.doi.org/10.1016/j.marchem.2005.09.010

Reeve, R. N. (2002). Introduction to environmental analysis. New York: Wiley. http://dx.doi.org/10.1002/0470845783

Ryan, J., Estefan, G., \& Rashid, A. (2007). Soil and plant analysis laboratory manual. Jodhpur: Scientific Publ.

Sadiq, M., \& Zaidi, T. H. (1994). Sediment composition and metal concentrations in mangrove leaves from the Saudi coast of the Arabian Gulf. Science of the total environment, 155(1), 1-8. http://dx.doi.org/10.1016/0048-9697(94)90356-5

Sadooni, F. N., \& El-kassas, I. A. (1999). Mangrove as a Bioindicator for Environmental Pollution in the Coastal Marine Environment. Review. Qatar Univ. Scij, 19. 
Salt, D. E., Smith, R. D., \& Raskin, I. (1998). Pytoremediation. Annual Review of Plant Physiology and Plant Molecular Biology, 49(1), 643-668. http://dx.doi.org/10.1146/annurev.arplant.49.1.643

Scott, D. A., IUCN., \& International Waterfowl and Wetlands Research Bureau. (1995). A directory of wetlands in the Middle East. Gland. Switzerland: IUCN.

Suresh, B., \& Ravishankar, G. A. (2004). Phytoremediation - a novel and promising approach for environmental $\begin{array}{llll}\text { clean-up. } \quad \text { Critical } & \text { Reviews }\end{array}$ http://dx.doi.org/10.1080/07388550490493627

Tam, N., \& Wong, Y. S. (1997). Accumulation and distribution of heavy metals in a simulated mangrove system treated with sewage. Hydrobiologia, 352, 1-3. http://dx.doi.org/10.1023/A:1003091532468

Tawfiq, N., \& Olsen, D. A. (1993). Saudi Arabia's response to the 1991 Gulf oil spill. Marine Pollution Bulletin, 27, 333-345. http://dx.doi.org/10.1016/0025-326X(93)90041-H

Terry, N., \& Banuelos, G. (2000). Phytoremediation of Trace Elements. Lewis Publishers, Boca Raton (pp. 389).

Usman, A. R., Alkredaa, R. S., \& Al-Wabel, M. I. (2013). Heavy metal contamination in sediments and mangroves from the coast of Red Sea: Avicennia marina as potential metal bioaccumulator. Ecotoxicology and environmental safety. http://dx.doi.org/10.1016/j.ecoenv.2013.08.009

Von, O. I., \& Max, F. C. (1984). Wastewater treatment with aquatic plants: Ecotypic differentiation of Typha domingensis seedlings. Environmental Pollution. Series A. Ecological and Biological, 35(3), 259-269. http://dx.doi.org/10.1016/0143-1471(84)90206-X

Wolterbeek, H. T., \& Van, M. A. J. (2002). Transport rate of arsenic, cadmium, copper and zinc in Potamogeton pectinatus L.: radiotracer experiments with $76 \mathrm{As}, 109,115 \mathrm{Cd}, 64 \mathrm{Cu}$ and $65,69 \mathrm{mZn}$. The Science of the Total Environment, 287, 1-2. http://dx.doi.org/10.1016/S0048-9697(01)00989-5

Xingmao, M., \& Havelka, M. M. (2009). Phytotoxicity of chlorinated benzenes to Typha angustifolia and Phragmites communis. Environmental Toxicology, 24(1), 43-48. http://dx.doi.org/10.1002/tox.20393

Zhao, F. J., Lombi, E., \& McGrath, S. P. (2003). Assessing the potential for zinc and cadmium phytoremediation with the hyperaccumulator Thlaspi caerulescens. Plant and Soil, 249(1), 37-43. http://dx.doi.org/10.1023/A:1022530217289

\section{Copyrights}

Copyright for this article is retained by the author(s), with first publication rights granted to the journal.

This is an open-access article distributed under the terms and conditions of the Creative Commons Attribution license (http://creativecommons.org/licenses/by/3.0/). 